\title{
NEW N-GLUCOSYLATED SUBSTITUTED ANILINES
}

\author{
Vsevolod Pogrebnoi \\ Institute of Chemistry of the Academy of Sciences of Moldova, 3, Academiei str., Chisinau MD-2028, Moldova \\ e-mail: seva.antivirus@gmail.com; phone: (+373 22) 739 754; fax: (+373 22) 739954
}

\begin{abstract}
The reaction of (+)-D-glucose 1 with 4-chloroaniline $\mathbf{6 b}$ or 3,5-dibromoaniline 12 leads almost exclusively to the $\beta$-configuration of $\mathrm{N}$-glucosylated anilines $\mathbf{7 b}$ and $\mathbf{1 3}$. Acetylated derivatives $\mathbf{8 b}, \mathbf{1 4}$ and $\mathbf{1 5}$ were obtained by dissolving/suspending substances $\mathbf{7 b}$ and $\mathbf{1 3}$ in $\mathrm{Ac}_{2} \mathrm{O} / \mathrm{Py}$ mixture. The acetylation of 2-(3,5-dibromophenylamino)-6-(hydroxymethyl)tetrahydro- $2 \mathrm{H}$-pyran-3,4,5-triol $\mathbf{1 3}$ is less selective than in the case of the 2-(4-chlorophenylamino)-6-(hydroxymethyl)tetrahydro-2H-pyran-3,4,5-triol $\mathbf{7 b}$ and leads to compounds 2-(acetoxymethyl)-6-(3,5-dibromophenylamino)tetrahydro-2H-pyran-3,4,5-triyl triacetate $\mathbf{1 4}$ and 2-(acetoxymethyl)6-(3,5-dibromophenylamino)-5-hydroxytetrahydro-2H-pyran-3,4-diyl diacetate $\mathbf{1 5}$ in a 2:1 ratio. The product $\mathbf{1 4}$ is formed with greater selectivity and in a higher yield (up to $80 \%$ ) when the reaction is catalyzed by DMAP and stored for one week at $+4^{\circ} \mathrm{C}$.
\end{abstract}

Keywords: N-glucosylated anilines, (+)-D-glucose, 4-chloroaniline, 3,5-dibromoaniline, Convolutamydines A-E.

Received: March 2015/ Revised final: October 2015/ Accepted: November 2015

\section{Introduction}

N-Glycosylated anilines represent an important product scaffold cluster by virtue of their bioactivity and as intermediates for generating further molecular complexity including natural compounds [1], for example some natural alkaloids. The vital roles played by sugars in biological systems continue to be unravelled. It is known that, various drugs, amino acids, sugars and many other chiral natural compounds show different influence on human organism, their biological properties being directly dependent on chirality. That is why the "structure-property" relationship should be studied very well. From the other side, properties are determined by the structure. It means, construction of chemically pure and defined molecule is an interesting and important goal in synthetic chemistry.

Langer et al. [1,2] has shortly offered the opinion that the preparation of analogues of N-glycosylated indolinones in high yields remains an important problem of carbohydrate and medicinal chemistry. This challenge also applies to the related problem of synthesis of N-linked alkaloids. For example, Kamano, Y. et al. [3], reported the isolation of the alkaloids - Convolutamydines A, B, and C from bryozoan Amathia convoluta, see Figure 1. In contrast to the pharmacologically inactive non-glycosylated indigo, $\mathrm{N}$-glycosylated indigo demonstrate a considerable growth inhibitory activity toward various human tumor cell lines $[4,5]$.

Our approaches to N-glucosylated indoline-2,3-dione 4 from (+)-D-glucose $\mathbf{1}$ and $\mathrm{N}$-glucosylated 3-hydroxy-2-oxindole 5 are presented below. They show benefit from the rapid advances in mainstream carbohydrate chemistry, allowing for convenient integration in glucosylated Convolutamydine A-E and analogues of structure 5 preparation (see Figure 1).

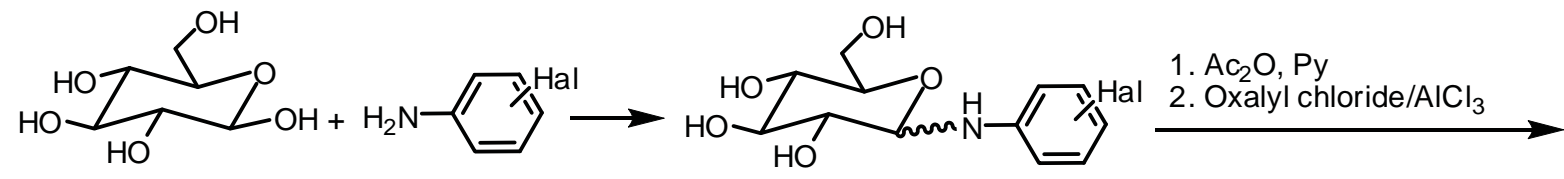

1 (Glucose)

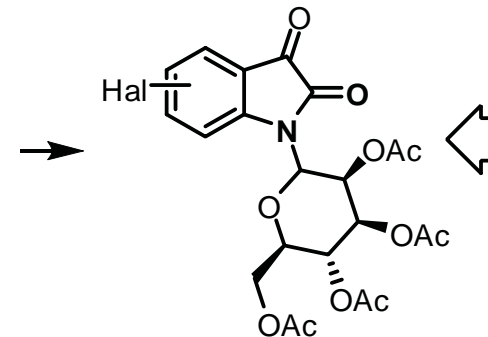

4
2

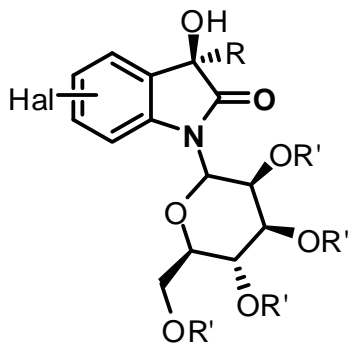

5<smiles>[R][C@]1(O)C(=O)Nc2cc(Br)cc(Br)c21</smiles>

Convolutamydine (A) $\mathrm{R}=\mathrm{CH}_{2} \mathrm{COMe}$ Convolutamydine (B) $\mathrm{R}=\mathrm{CH}_{2} \mathrm{CH}_{2} \mathrm{Cl}$ Convolutamydine (C) $\mathrm{R}=\mathrm{Me}$ Convolutamydine (D) $\mathrm{R}=\mathrm{CH}=\mathrm{CH}_{2}$ Convolutamydine (E) $\mathrm{R}=\mathrm{CH}_{2} \mathrm{CH}_{2} \mathrm{OH}$

Figure 1. Synthesis of N-glucosylated indoline-2,3-dione (4). 
The main purpose of the present research was to test the effectiveness of this approach for the synthesis of halogen phenylamino-6-(hydroxymethyl)tetrahydro-2H-pyran-3,4,5-triyl triacetates from the corresponding intermediates 3 (see Figure 1). It has already been demonstrated that such type compounds are suitable building units for the synthesis of a variety of non-halogenated isatin-N-glucosides [1,2]. We also report in this paper the preparation of 3,5-dibromoaniline 12.

\section{Results and discussion}

It was reported [1], that similar aniline- $N$-glucosides 7a were prepared from corresponding anilines $(\mathrm{R}=\mathrm{H}, \mathrm{Me}$, $i$-Pr, $t$-Bu) and $(+)$ - $D$-glucose 1 . The formed product $7 \mathbf{a}$ was directly used for the next step (see Scheme 1). However, some of the derivatives of glycosides can be isolated as pure $\beta$-anomers 8a, whereas the others contain a small amount of the corresponding $\alpha$-anomer [1,2].

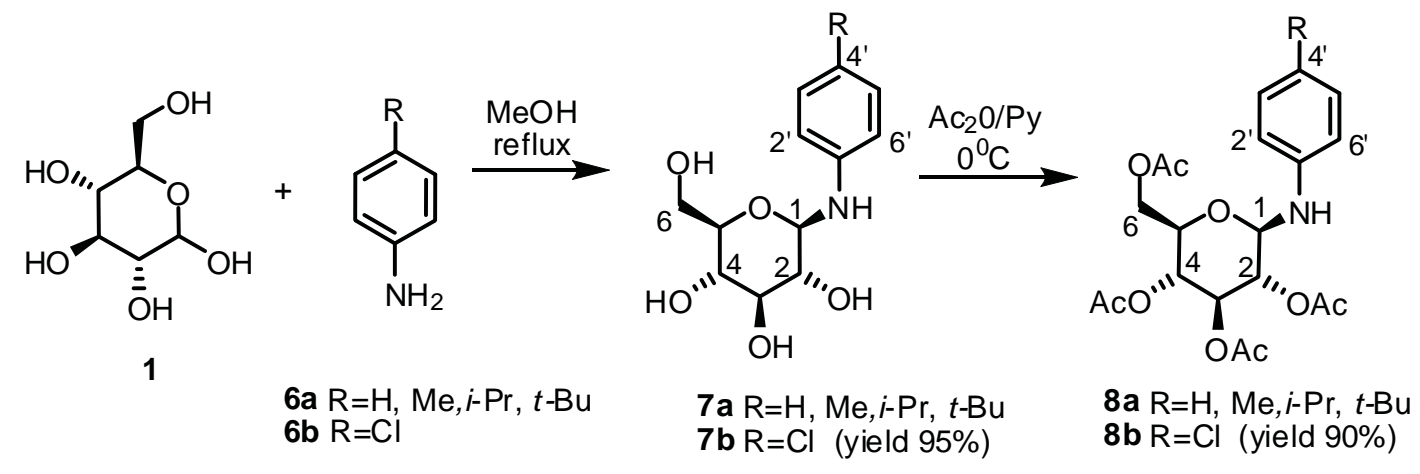

Scheme 1. Syntheses of $\mathbf{N}$-glucosylated 4-substituted anilines $8 \mathrm{a}$ and $8 \mathrm{~b}$ [1].

In the course of our studies the $(2 R, 3 R, 4 S, 5 S, 6 R)-2$-(4-chlorophenylamino)-6-(hydroxymethyl)tetrahydro- $2 H$ pyran-3,4,5-triol 7b was prepared according to the reported method [1] primarily by reason of convenience: medium solubility of (+)-D-glucose 1 in $\mathrm{MeOH}$ and easy removal from the excess of aniline by filtration and washing with cool $\mathrm{MeOH}$, provides ready access to the solid aminoglycoside, which is slightly soluble in $\mathrm{MeOH}$. A mixture of $(+)-D$-glucose 1 and 4-chloroaniline $\mathbf{6 b}$ was refluxed for 12 hours (see Scheme 1). TLC of the reaction mixture indicated the disappearance of the starting glucose $\mathbf{1}$ and an increase in the intensity of the neighbouring spot. On keeping the solution overnight in the refrigerator an adduct precipitated that was easily isolated by filtration, being then identified as compound 7b. It had m.p. 154-156 ${ }^{\circ} \mathrm{C}$ and characteristic IR absorption bands $v_{\mathrm{OH}}$ at 3271 and $3209 \mathrm{~cm}^{-1}$, the primary (C6) and secondary (C-2, C-3 and C-4) nature of the alcohol functions being confirmed by the ${ }^{1} \mathrm{H}$ NMR spectrum (triplet at $\delta_{\mathrm{H}} 4.44-4.47 \mathrm{ppm}$ with a splitting constant $J=5.8 \mathrm{~Hz}$ and three doublets at $\delta_{\mathrm{H}} 4.88-4.90,4.92-4.9$ and 5.00-5.02 ppm with splitting constants $J=5.4 \mathrm{~Hz}, J=5.2 \mathrm{~Hz}$ and $J=4.7 \mathrm{~Hz}$. NH group shows doublet at $\delta_{\mathrm{H}} 6.46-6.48 \mathrm{ppm}$. Moreover, ${ }^{1} \mathrm{H}$ NMR spectrum has resonances at $\delta_{\mathrm{H}} 6.67-6.69 \mathrm{ppm}\left(\mathrm{C}-2^{\prime}-\mathrm{H}\right.$ and $\mathrm{C}-6^{\prime}-\mathrm{H}$, doublet, $\left.J=8.8 \mathrm{~Hz}\right)$ and $\delta_{\mathrm{H}} 7.10-7.12 \mathrm{ppm}\left(\mathrm{C}-3^{\prime}-\mathrm{H}\right.$ and $\mathbf{C}-5^{\prime}-\mathrm{H}$, doublet, $J=8.8 \mathrm{~Hz}$ ), indicating that compound $\mathbf{7 b}$ is an anilide. Additionally, absorption in the low-field region of its ${ }^{13} \mathrm{C}$ NMR spectrum confirmed the presence of aromatic carbons at $\delta_{\mathrm{C}} 115.06 \mathrm{ppm}(\mathrm{C}-2$ ' and C-6'), 120.7 ppm (C-4'), 128.92 ppm (C-3' and C-5') ppm and 146.7 ppm (C-1').

In fact compound $7 \mathbf{b}$ shows in the ${ }^{1} \mathrm{H}$ NMR spectrum a clear triplet at $\delta_{\mathrm{H}} 4.30-4.34 \mathrm{ppm}$ with the magnitude of a spin-spin coupling constant $J=8 \mathrm{~Hz}$ and an important peak at $883.8 \mathrm{~cm}^{-1}$ in its IR-spectrum, which is characteristic for a $\beta$-anomer.

The reaction of compound $7 \mathbf{b}$ with (+)-D-glucose 1 was slow and only after 48 hrs provided a solid compound with m.p. $146-149^{\circ} \mathrm{C}$. The substance 8b was obtained in $97 \%$ yield, being identified as $(2 R, 3 R, 4 S, 5 S, 6 R)-2-(4-$ chlorophenylamino)-6-(hydroxymethyl)tetrahydro- $2 \mathrm{H}$-pyran-3,4,5-triol $\mathbf{8 b}$ on the basis of its NMR spectroscopic data. Thus, the ${ }^{1} \mathrm{H}$ NMR spectrum of it showed in the low-field region two singlets and a doublet at $\delta_{\mathrm{H}} 1.95,1.97,2.00 \mathrm{ppm}$ characterizing four acetate groups, according to the integral. The ${ }^{1} \mathrm{H}$ NMR spectrum of compound $\mathbf{8 b}$ also contains two doublets of aromatic protons, centered at $\delta_{\mathrm{H}} 6.75 \mathrm{ppm}\left(2 \mathrm{H}, \mathrm{C}-2^{\prime}-\mathrm{H}\right.$ and $\left.\mathrm{C}-6{ }^{\prime}-\mathrm{H}, \mathrm{J}=8.9 \mathrm{~Hz}\right)$ and $\delta_{\mathrm{H}} 7.14 \mathrm{ppm}(2 \mathrm{H}$, $\mathrm{C}-3^{\prime}-\mathrm{H}$ and $\mathrm{C}-5^{\prime}-\mathrm{H}, \mathrm{J}=8.8 \mathrm{~Hz}$ ) and a doublet of $\mathrm{NH}$ group at $\delta_{\mathrm{H}} 6.71 \mathrm{ppm}$ with the spin-spin coupling constant $\mathrm{J}=9.8$ $\mathrm{Hz}$. The ${ }^{13} \mathrm{C}$ NMR spectroscopic data totally confirm the structure $\mathbf{8 b}$, see experimental part. Thus, the preparation of $(2 R, 3 R, 4 S, 5 S, 6 R)-2$-(4-chlorophenylamino)-6-(hydroxymethyl)tetrahydro-2H-pyran-3,4,5-triol $\mathbf{8 b}$ via aniline- $\mathrm{N}$ glucoside $\mathbf{7 b}$ has been successfully reproduced by us.

It was found that the 4,6-dibromohydroxyoxindole nucleus exhibit a potent activity in the differentiation of HL-60 human promyelocytic cells $[3,6]$. Therefore, as a part of the program aimed at developing new N-glucosylated oxindoles, we supposed, that the 3,5-dibromoaniline 12 scaffold has potential to enhance the selectivity. As obvious precursor for the synthesis of glucosylated Convolutamydines A-E 5, 3,5-dibromoaniline 12 was prepared by initial bromination of 4-nitroaniline 9, followed by deamination of aniline 10, to form 3,5-dibromonitrobenzene 11. $\mathrm{SnCl}_{2}$ 
reduction of the latter was found to proceed with difficultly, but when 5 equivalents of $\mathrm{SnCl}_{2}$ were used, 3,5-dibromoaniline 12 has been produced in good yield (see Scheme 2 and experimental part).

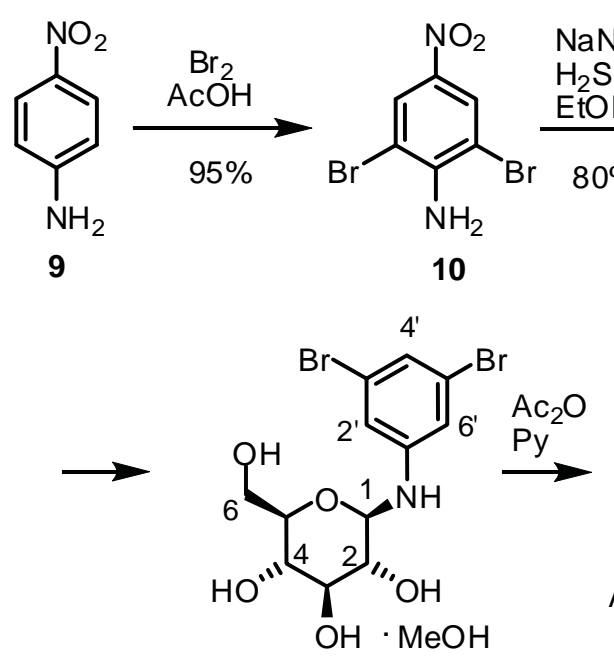

13

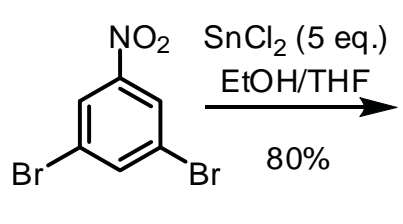

11

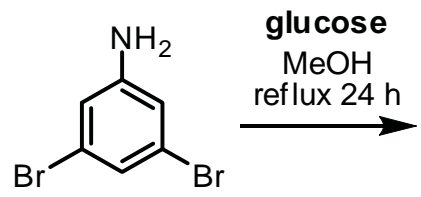

12

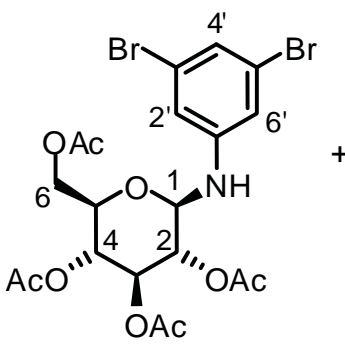

14

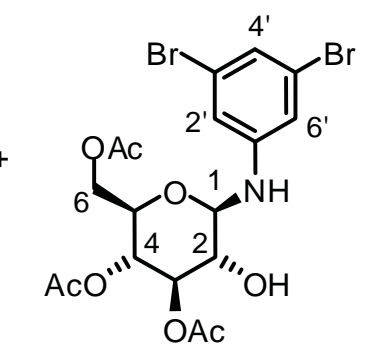

15

Scheme 2. Synthesis of 3,5-dibromoaniline (12) and its N-glucosylated derivatives 13, 14 and 15.

As it can be seen from Scheme 2, the reaction of 12 with (+)-D-glucose 1 was slow and only after 24 hrs provided a solid compound with m.p. $169-170^{\circ} \mathrm{C}$. The substance obtained in $97 \%$ yield was identified as $(2 R, 3 R, 4 S, 5 S, 6 R)-2-$ (3,5-dibromophenylamino)-6-(hydroxymethyl)tetrahydro- $2 \mathrm{H}$-pyran-3,4,5-triol 13 on the basis of its ${ }^{1} \mathrm{H} N M R$ spectrum, which showed in the low-field region signals at $\delta_{\mathrm{H}} 6.86 \mathrm{ppm}$ and $\delta_{\mathrm{H}} 6.95 \mathrm{ppm}$ (aromatic), $\delta_{\mathrm{H}} 6.89 \mathrm{ppm}(\mathrm{NH}), \delta_{\mathrm{H}} 4.52 \mathrm{ppm}$, $\delta_{\mathrm{H}} 4.96 \mathrm{ppm}, \delta_{\mathrm{H}} 4.97 \mathrm{ppm}$ and $\delta_{\mathrm{H}} 5.05 \mathrm{ppm}\left(\mathrm{C}-6-\mathrm{OH}, \mathrm{C}-4-\mathrm{OH}, \mathrm{C}-2-\mathrm{OH}\right.$ and $\mathrm{C}-3-\mathrm{OH}$, respectively). Moreover, in its ${ }^{1} \mathrm{H}$ spectrum the multiplets at $\delta_{\mathrm{H}} 3.10-3.24 \mathrm{ppm}(\mathrm{C}-2-\mathrm{H}, \mathrm{C}-3-\mathrm{H}, \mathrm{C}-4-\mathrm{H}, \mathrm{C}-5-\mathrm{H}, \mathrm{C}-6-\mathrm{H})$ and triplet centred at $\delta_{\mathrm{H}} 4.36 \mathrm{ppm}$ $(\mathrm{C}-1-\mathrm{H})$ are present. The IR-spectrum showed a low intensity band at $892.4 \mathrm{~cm}^{-1}$ assigned to the $\mathrm{C}-1-\mathrm{H}$ scissoring of the protons in the $\beta$-anomer. Similarly, the ${ }^{1} \mathrm{H}$ NMR spectrum indicated the presence of C-1-H (a triplet at $\delta_{\mathrm{H}} 4.36 \mathrm{ppm}$ with a splitting constant $J=8 \mathrm{~Hz}$. However, ${ }^{1} \mathrm{H}$ NMR spectrum shows two additional signals: a doublet attributable to three protons for methanol at $\delta_{\mathrm{H}} 3.17 \mathrm{ppm}$ and a quartet of one proton at $\delta_{\mathrm{H}} 6.95 \mathrm{ppm}(\mathrm{OH})$, shielded by an additional carbon, which appears in ${ }^{13} \mathrm{C}$ NMR spectrum at $\delta_{\mathrm{C}} 49.10 \mathrm{ppm}$. Finally, the structure of the product is considered to be $\mathbf{1 3}$ on the basis of its elemental analysis, as well. The formation of intermolecular complex $\mathbf{1 3}$ has been rationalized by considering the participation of the hydroxyl, as well as $\mathrm{NH}$ groups in the addition of $\mathbf{1 2}$ with $(+)$ - $D$-glucose in $\mathrm{MeOH}$ medium.

The acetylation reaction of $\mathbf{1 3}$ was performed with acetic anhydride in pyridine and lead to esters $\mathbf{1 4}$. The reaction was very slow (one week) and after work-up two main products in the obtained mixture were then separated by column chromatography over silica gel.

As a result, pure 14 was isolated as the least polar product with m.p. $72-73^{\circ} \mathrm{C}$ in $35 \%$ yield and its structure has been proved by NMR. The ${ }^{1} \mathrm{H}$ NMR spectrum of it contains singlets at $\delta_{\mathrm{H}} 2.03 \mathrm{ppm}, \delta_{\mathrm{H}} 2.06 \mathrm{ppp}, \delta_{\mathrm{H}} 2.07 \mathrm{ppm}, \delta_{\mathrm{H}} 2.11$ ppm (AcO groups), a doublet centered at $\delta_{\mathrm{H}} 5.04 \mathrm{ppm}(J=9.7 \mathrm{~Hz})\left(\mathrm{NH}\right.$ group), multiplets at $\delta_{\mathrm{H}} 3.86,4.68,5.00,5.04$, $5.37 \mathrm{ppm}\left(\mathrm{C} 2-\mathrm{H}, \mathrm{C} 3-\mathrm{H}, \mathrm{C} 4-\mathrm{H}, \mathrm{C} 5-\mathrm{H}, \mathrm{C} 6-\mathrm{H}\right.$, correspondingly), multiplets at $\delta_{\mathrm{H}} 4.14$ and $4.23 \mathrm{ppm}\left(\mathrm{CH}_{2}\right)$, and doublet of aromatic protons at $\delta_{\mathrm{H}} 6.74 \mathrm{ppm}\left(2 \mathrm{H}, J=1.5, \mathrm{C}-2^{\prime}-\mathrm{H}, \mathrm{C}-6^{\prime}-\mathrm{H}\right)$ and $\delta_{\mathrm{H}} 7.11 \mathrm{ppm}\left(1 \mathrm{H}, \mathrm{t}, J=1.5, \mathrm{C}-4^{\prime}-\mathrm{H}\right)$.

Moreover, its formulation as an ester has been sustained by peaks in higher field ${ }^{13} \mathrm{C}$ NMR spectrum at $\delta_{\mathrm{C}} 72.7 \mathrm{ppm}(\mathrm{C}$ 5), 68.9 (C-4), 72.5 (C-3), 71.0 (C-2), 83.6 (C-1) and 146.7 ppm (C-1') and peaks in lower field at $\delta_{\mathrm{C}} 62.3$ (C-6), 115.9 (C-2', C-6'), 123.2 (C-3', C-5') and $125.1 \mathrm{ppm}$ (C-4'). This resonance pattern differs markedly from that observed for the initial compound 13. The comparative examination also suggests that four acetyl group functions should have eight peaks as well. This is consistent with the observation of signals at $\delta_{\mathrm{C}} 20.6\left(\mathrm{CH}_{3}\right), 20.65\left(\mathrm{CH}_{3}\right), 20.7\left(\mathrm{CH}_{3}\right), 20.8\left(\mathrm{CH}_{3}\right)$, $170.7(\mathrm{C}=\mathrm{O}), 169.6(\mathrm{C}=\mathrm{O}), 169.9(\mathrm{C}=\mathrm{O})$ and $171.3(\mathrm{C}=\mathrm{O})$. The IR-spectrum showed bands at $1740 \mathrm{~cm}^{-1}, 1588 \mathrm{~cm}^{-1}$, $3371 \mathrm{~cm}^{-1}, 915 \mathrm{~cm}^{-1}$ and $671 \mathrm{~cm}^{-1}$ assigned to the $\mathrm{COO}$, aromatic, $\mathrm{NH}, \beta$-glucopyranoside and $\mathrm{C}$ - $\mathrm{Br}$, respectively.

Additionally, another product was isolated, which presumably corresponded to the structure 15. According to NMR data, the isolated product is a mixture of compounds $\mathbf{1 4}$ and $\mathbf{1 5}$ in 2:1 ratio, which has been determined by integration of the signals belonging to the acetate groups. It could be easily identified according to ${ }^{13} \mathrm{C}$ NMR spectrum by the double set of signals: four $\mathrm{C}=\mathrm{O}$ groups at $\delta_{\mathrm{C}} 169.6,169.9,170.7$ and $171.3 \mathrm{ppm}$ for compound 14 , and three $\mathrm{C}=\mathrm{O}$ groups for compound 15 at $\delta_{\mathrm{C}} 169.1,169.5$ and 170.4 respectively. Similarly, double set of signals has been noted for pyranic $\left(\delta_{\mathrm{C}} 60-83 \mathrm{ppm}\right)$ and aromatic $\left(\delta_{\mathrm{C}} 115-147 \mathrm{ppm}\right)$ parts of molecules of the discussed derivative (see experimental 
part). Thus, the ${ }^{1} \mathrm{H}$ NMR spectrum shows multiplets at $\delta_{\mathrm{H}} 3.85-3.90,4.01-4.30,4.99-5.07,5.16-5.20$ and 5.30-5.46 ppm, which are characteristic for pyranic part $(\mathrm{CH}$ and $\mathrm{OH})$, two doublets at $\delta_{\mathrm{H}} 6.74$ and $7.00 \mathrm{ppm}$ and two triplets centered at $\delta_{\mathrm{H}} 7.10$ and $7.14 \mathrm{ppm}$ (aromatic), four singlets at $\delta_{\mathrm{H}} 2.04,2.05,2.06$ and $2.07 \mathrm{ppm}$ for compound 14, a singlet at $\delta_{\mathrm{H}} 2.03$ $\mathrm{ppm}$ and a doublet centered at $\delta_{\mathrm{H}} 2.08 \mathrm{ppm}$ for compound 15, respectively.

Catalysis by pyridine is of the nucleophilic type and it is known that 4-(N,N-dimethylamino)pyridine is a better catalyst when pyridine fails. Indeed, compound $\mathbf{1 3}$ readily undergoes reaction with acetic anhydride under analogues conditions in presence 4-(N,N-dimethylamino)pyridine to yield up to $90 \%$ compound $\mathbf{1 4}$.

\section{Conclusions}

The present work demonstrates that interaction of 4-chloro- and 3,5-dibromo- substituted anilines with $(+)$ - $D$-glucose affords $\mathrm{N}$-glycosylated adducts $\mathbf{7 b}$ and $\mathbf{1 3}$ as $\beta$-anomers. The position and steric course of further estherification are catalytically dependent. We confirmed that in the case of 4-chloro substituted aniline reaction with $\mathrm{Ac}_{2} \mathrm{O}$ in Py occurs mainly to give tetra-acetate $\mathbf{8 b}$. On the contrary, reaction of 3,5-dibromo substituted aniline gives a mixture of adducts $\mathbf{1 4}$ and $\mathbf{1 5}$ in a 2:1 ratio with overall yield $65 \%$. In the case when the reaction was catalysed by $4-(\mathrm{N}, \mathrm{N}$-dimethylamino)pyridine only compound $\mathbf{1 4}$ was obtained in $80 \%$ overall yield. The structures of all new compounds 13, 14 and 15, including configurations of anomeric carbon atoms, were characterized through IR and NMR spectroscopic methods.

\section{Experimental}

All used solvents were of reagent quality, and all commercial reagents were used without additional purification. Removal of all solvents was carried out under reduced pressure. Analytical TLC plates Silufol ${ }^{\circledR}$ UV-254 (Silpearl on aluminum foil, Czecho-Slovakia) were used and spots were detected under UV-lamp with wavelength $254 \mathrm{~nm}$.

M. p.s (uncorrected) were determined on a Boetius apparatus.

IR spectra were recorded on a Spectrum 100 FT-IR spectrophotometer (Perkin - Elmer) using the universal ATR sampling accessory. ${ }^{1} \mathrm{H}$ and ${ }^{13} \mathrm{C}$ NMR spectra were registered in $\mathrm{CDCl}_{3}$ and DMSO- $\mathrm{d}_{6} 2-\%$ solution on a "Bruker-Avance III" (400.13 and 100.61 MHz) spectrometer.

\section{General procedure for the synthesis of $\mathbf{N}$-glucosylated anilines $\mathbf{7 b}$ and $\mathbf{1 3 .}$}

To a solution of (+)-D-glucose $\mathbf{1}(2 \mathrm{~g}, 0.011 \mathrm{~mol})$ in $25 \mathrm{~mL}$ of absolute methanol corresponding aniline (6b or 12) (0.013 $\mathrm{mol}$ ) was added. The mixture was refluxed for 24 hours. After completion of the reaction (TLC control, solvent system $2 \% \mathrm{MeOH}$ in $\mathrm{CH}_{2} \mathrm{Cl}_{2}$ ) the mixture was stored in refrigerator at sub-zero temperature so long, as white volume is being precipitated. The precipitate was filtered and washed with methanol and dried at room temperature.

(2R,3R,4R,5R,6R)-2-(4-chlorophenylamino)-6-(hydroxymethyl)tetrahydro-2H-pyran-3,4,5-triol 7b. White solid. Yield $95 \%$. M. p. $154-156^{\circ} \mathrm{C}(\mathrm{MeOH})$. $[\alpha]_{\mathrm{D}}{ }^{20}-41.0\left(\mathrm{c} 0.068\right.$, DMSO). IR-spectra $\left(\mathrm{v} / \mathrm{cm}^{-1}\right): 3271.5,3209.1(\mathrm{OH})$, $1523.4(\mathrm{NH}), 883.8(\mathrm{C}-1-\mathrm{H}), 683.3(\mathrm{C}-\mathrm{Cl}){ }^{1}{ }^{1} \mathrm{H}$ NMR (400 MHz, DMSO- $\left.\mathrm{d}_{6}, \delta, \mathrm{ppm}, \mathrm{J} / \mathrm{Hz}\right): 3.07-3.27(4 \mathrm{H}, \mathrm{m}, \mathrm{C}-2-\mathrm{H}$, C-3-H, C-4-H, C-5-H), 3.39-3.45 (1H, m, C-6-H), 3.61-3.66 (1H, m, C-6-H), 4.30-4.34 (1H, t, C-1-H, J=8), 4.44-4.47 $(1 \mathrm{H}, \mathrm{t}, \mathrm{C}-6-\mathrm{OH}, \mathrm{J}=5.8), 4.88-4.90(1 \mathrm{H}, \mathrm{d}, \mathrm{C}-4-\mathrm{OH}, \mathrm{J}=5.4), 4.92-4.93(1 \mathrm{H}, \mathrm{d}, \mathrm{C}-2-\mathrm{OH}, \mathrm{J}=5.2), 5.00-5.02(1 \mathrm{H}, \mathrm{d}, \mathrm{C}-3-$ OH, J=4.7), 6.46-6.48 (1H, d, NH, J=7.5), 6.67-6.69 (2H, d, C-2'-H, C-6'-H, J=8.8), 7.10-7.12 (2H, d, C-3'-H, C-5'-H, $\mathrm{J}=8.8) .{ }^{13} \mathrm{C}$ NMR (100.6 MHz, DMSO-d $\left.{ }_{6}\right): 61.4$ (C-6), 70.6 (C-4), 73.5 (C-2), 77.8 (C-3), 78.1 (C-5), 85.3 (C-1), 115.0 (C-2', C-6'), 120.7 (C-4'), 128.9 (C-3', C-5'), 146.8 (C-1'). Calculated, \%: C 49.75; H 5.57; N 4.83. $\mathrm{C}_{12} \mathrm{H}_{16} \mathrm{ClNO}_{5}$. Found, \%: C 49.80; H 5.60; N 4.80.

(2R,3R,4S,5S,6R)-2-(3,5-dibromophenylamino)-6-(hydroxymethyl)tetrahydro-2H-pyran-3,4,5-triol 13 . White solid. Yield $97 \%$. M. p. $169-170^{\circ} \mathrm{C}(\mathrm{MeOH})$. $[\alpha]_{\mathrm{D}}{ }^{20}-62.40$ (c 0.05, DMSO). IR-spectra $\left(\mathrm{v} / \mathrm{cm}^{-1}\right): 3367.5,3210.1$, $3073.2(\mathrm{OH}) ; 1518.0(\mathrm{NH}) ; 892.4(\mathrm{C}-1-\mathrm{H}), 668.2(\mathrm{C}-\mathrm{Br}), 1574.5$ (aromatics), 3367-3073 (OH). ${ }^{1} \mathrm{H}$ NMR $(400 \mathrm{MHz}$, DMSO- $\left.\mathrm{d}_{6}, \delta, \mathrm{ppm}, \mathrm{J} / \mathrm{Hz}\right): 3.40-3.65$ (1H, ddd, J=11.8, 5.8, 1.9, C-6-H), 3.1 (2H, m, C-4-H, C-2-H), 3.24 (2H, m, C-5-H, $\mathrm{C}-3-\mathrm{H}), 3.17\left(3 \mathrm{H}, \mathrm{d}, \mathrm{J}=5.2, \underline{\mathrm{CH}}_{3} \mathrm{OH}\right), 4.18\left(1 \mathrm{H}, \mathrm{q}, \mathrm{J}=5.2, \mathrm{CH}_{3} \mathrm{OH}\right), 4.36(1 \mathrm{H}, \mathrm{t}, \mathrm{J}=8, \mathrm{C}-1-\mathrm{H}), 4.52(1 \mathrm{H}, \mathrm{t}, \mathrm{J}=5.8, \mathrm{C}-6-\mathrm{OH})$, 4.96, (1H, d, J=1.7, C-4-OH), 4.97 (1H, d, J=1.4, C-2-OH), 5.05 (1H, d, J=4.8, C-3-OH), 6.89 (1H, d, J=7.8, NH), 6.86 $\left(2 \mathrm{H}, \mathrm{d}, \mathrm{J}=7.6, \mathrm{C}-2\right.$ '-H, C-6'-H), 6.95 (1H, t, J=1.6, C-4'-H). ${ }^{13} \mathrm{C}$ NMR (100.6 MHz, DMSO-d $)$ : 49.1 ( $\left.\mathrm{MeOH}\right), 61.3(\mathrm{C}-$ 6), 70.7 (C-4), 73.5 (C-2), 77.8 (C-3), 77.9 (C-5), 84.5 (C-1), 115.1 (C-2'and C-6'), 121.5 (C-4'), 123.1 (C-3' and C-5'), 150.7 (C-1'). Calculated, \%: C 34.89; H 3.66; N 3.39. $\mathrm{C}_{12} \mathrm{H}_{15} \mathrm{Br}_{2} \mathrm{NO}_{5}$. Found, \%: C 34.94; H 3.64; N 3.41.

\section{Procedure for the synthesis of compound $8 \mathrm{~b}$.}

The anilide $\mathbf{7 b}$ is maximally dissolved in dry pyridine under stirring (for every hydroxyl group 1.8-2.0 eq. of pyridine are used) and cooled in an ice bath to $0^{\circ} \mathrm{C}$. Then, freshly distillated acetic anhydride is rapidly added (for every hydroxyl group 1.5-1.6 eq. of acetic anhydride are used). Stirring is continued at the same temperature until a homogeneous solution appeared (about 3 hours). The mixture was hold for 24-48 hours in a refrigerator without stirring. After completion of the 
reaction (TLC control, system hexane-ethyl acetate 4:1), the mixture was poured into ice-water (1:2) and extracted with ethyl acetate $(4 \times 30 \mathrm{~mL})$. The combined organic phases were washed with sodium hydrogen carbonate solution, water and brine, dried over anhydrous sodium sulfate and the solvent was removed under reduced pressure. The resulting white solid mass was recrystallised from methanol. The bittern was evaporated and recrystallised again. The obtained product is white solid.

(2R,3R,4S,5R,6R)-2-(acetoxymethyl)-6-(4-chlorophenylamino)tetrahydro-2H-pyran-3,4,5-triyl triacetate $8 \mathrm{~b}$. White solid. Yield $97 \%$. M. p. 146-149 ${ }^{\circ} \mathrm{C}(\mathrm{MeOH}) .[\alpha]_{\mathrm{D}}{ }^{20}-48.6\left(\mathrm{c} 0.076, \mathrm{CHCl}_{3}\right)$. IR-spectra $\left(\mathrm{v} / \mathrm{cm}^{-1}\right): 1059.5$, 1180.7 (C-O-C), 1511.7 (NH), 878.9 (C-1-H), 688.4 (C-Cl). ${ }^{1} \mathrm{H}$ NMR (400 MHz, DMSO-d, $\left., \delta, \mathrm{ppm}, \mathrm{J} / \mathrm{Hz}\right): 1.95$ (3H, s, $\left.\underline{\mathrm{CH}}_{3} \mathrm{CO}\right), 1.95$ (3H, s, $\left.\underline{\mathrm{CH}}_{3} \mathrm{CO}\right), 1.97\left(3 \mathrm{H}, \mathrm{s}, \underline{\mathrm{CH}}_{3} \mathrm{CO}\right), 2.00\left(3 \mathrm{H}, \mathrm{s}, \underline{\mathrm{CH}}_{3} \mathrm{CO}\right), 4.08-4.18(2 \mathrm{H}, \mathrm{m}, \mathrm{C}-6), 4.88-4.93(2 \mathrm{H}$, ddd, C-5-H and C-4-H, J=0.9; 1.6; 2.1), 3.93-3.97 (1 $\mathrm{H}, \mathrm{dd}, \mathrm{C} 3-\mathrm{H}, \mathrm{J}=1.8 ; 1.8), 5.18-5.22(1 \mathrm{H}, \mathrm{t}, \mathrm{C}-3-\mathrm{H}, \mathrm{J}=9.4), 5.32-5.36$ $(1 \mathrm{H}, \mathrm{t}, \mathrm{C}-1-\mathrm{H}, \mathrm{J}=9.5), 6.71(1 \mathrm{H}, \mathrm{d}, \mathrm{NH}, \mathrm{J}=9.8), 6.75\left(2 \mathrm{H}, \mathrm{d}, \mathrm{C}-2^{\prime}-\mathrm{H}\right.$ and C-6'-H, J=8.9), 7.14 (2H, d, C-3'-H and C-5' $-\mathrm{H}$, $\mathrm{J}=8.8) .{ }^{13} \mathrm{C}$ NMR (100.6 MHz, DMSO-d 6$): 20.8\left(\mathrm{CH}_{3}\right), 20.8\left(\mathrm{CH}_{3}\right), 20.9\left(\mathrm{CH}_{3}\right), 20.9\left(\mathrm{CH}_{3}\right), 62.3(\mathrm{C}-6), 68.7(\mathrm{C}-4), 71.2$ (C-3), 71.5 (C-5), 73.7 (C-2), 82 (C-1), 115.8 (C-2' and C-6'), 122.0 (C-4'), 129 (C-3' and C-5'), 145.5 (C-1'), 169.6 $(\mathrm{C}=\mathrm{O}), 169.8(\mathrm{C}=\mathrm{O}), 170.1(\mathrm{C}=\mathrm{O}), 170.4(\mathrm{C}=\mathrm{O})$. Calculated, \%: C 52.46; H 5.28; N 3.06. $\mathrm{C}_{20} \mathrm{H}_{24} \mathrm{ClNO}_{9}$. Found, \%: C $52.52 ; \mathrm{H} 5.30 ; \mathrm{N} 3.10$.

\section{General procedure for the synthesis of compounds 14 and 15.}

Method A: The anilide 13 is maximally dissolved in dry pyridine under stirring (for every hydroxyl group 1.8-2.0 eq. of pyridine are used) and cooled in an ice bath to $0^{\circ} \mathrm{C}$. Then, freshly distillated acetic anhydride is rapidly added (for every hydroxyl group 1.5-1.6 eq. of acetic anhydride are used). Stirring is continued at the same temperature until a homogeneous solution appeared (about 3 hours). The mixture was hold for 24-48 hours in a refrigerator without stirring. After completion of the reaction (TLC control, system hexane-ethyl acetate 4:1), the mixture was poured into ice-water $(1: 2)$ and extracted with ethyl acetate $(4 \times 30 \mathrm{~mL})$. The combined organic phases were washed with sodium hydrogen carbonate solution, water and brine, dried over anhydrous sodium sulfate and the solvent was removed under reduced pressure. The resulting oily mass was purified by column chromatography on silica gel, using as eluent hexane-ethyl acetate (6:1 to $3: 1)$.

Method B: The anilide $\mathbf{1 3}$ is maximally dissolved in dry pyridine under stirring. For every hydroxyl group is used 1.82.0 eq. of pyridine, and cooled in an ice bath to $0^{\circ} \mathrm{C}$. Then, freshly distillated acetic anhydride is added rapidly. For every hydroxyl group is used 1.5-1.6 eq., of acetic anhydride. Then $10 \mathrm{~mol} \%$ of DMAP (catalyst) was added and stirring was continued at the same temperature until a homogeneous solution (about 3 hours). The mixture was hold for one week in a refrigerator without stirring. After completion of the reaction (TLC control, system hexane-ethyl acetate 4:1), the mixture was poured into ice-water $(1: 2)$ and extracted with ethyl acetate $(4 \times 30 \mathrm{~mL})$. The combined organic phases were washed with sodium hydrogen carbonate solution, water and brine, dried over anhydrous sodium sulfate and the solvent was removed under reduced pressure. The resulting oily was purified by column chromatography on silica gel, using as eluent hexane-ethyl acetate $(6: 1$ to $3: 1)$.

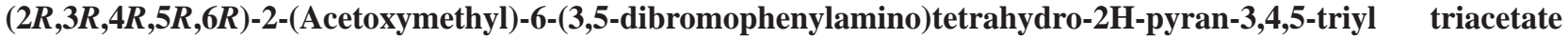
14. White solid. Yield $60 \%$. M. p. $72-73^{\circ} \mathrm{C}(\mathrm{MeOH})$. $[\alpha]_{\mathrm{D}}{ }^{16}-38.45$ (c $\left.0.098, \mathrm{CHCl}_{3}\right)$. IR-spectra $\left(\mathrm{v} / \mathrm{cm}^{-1}\right)$ :

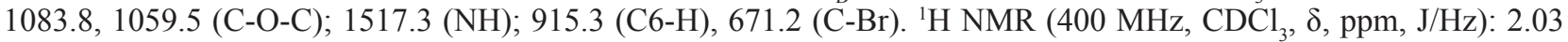
$\left(3 \mathrm{H}, \mathrm{s}, \underline{\mathrm{CH}}_{3} \mathrm{CO}\right), 2.06\left(3 \mathrm{H}, \mathrm{s}, \underline{\mathrm{CH}}_{3} \mathrm{CO}\right), 2.07\left(3 \mathrm{H}, \mathrm{s}, \underline{\mathrm{CH}}_{3} \mathrm{CO}\right), 2.11\left(3 \mathrm{H}, \mathrm{s}, \underline{\mathrm{CH}}_{3} \mathrm{CO}\right), 3.86$ (1H, ddd, J=10.1, 6.3, 2.1, C-5-H), $4.14(1 \mathrm{H}, \mathrm{dd}, \mathrm{J}=12.1,2.1, \mathrm{C}-6-\mathrm{H}), 4.23(1 \mathrm{H}, \mathrm{d} d \mathrm{~d}, \mathrm{~J}=12.1,6.3, \mathrm{C}-6-\mathrm{H}), 4.68(1 \mathrm{H}, \mathrm{t}, \mathrm{J}=8.8, \mathrm{C}-1-\mathrm{H}), 5.00(1 \mathrm{H}$, t, J=9.1, C-2-H), $5.04(1 \mathrm{H}, \mathrm{t}, \mathrm{J}=9.7, \mathrm{C}-4-\mathrm{H}), 5.04(1 \mathrm{H}, \mathrm{d}, \mathrm{J}=8.8, \mathrm{NH}), 5.37(1 \mathrm{H}, \mathrm{t}, \mathrm{J}=9.1, \mathrm{C}-3-\mathrm{H}), 6.74(2 \mathrm{H}, \mathrm{d}, \mathrm{J}=1.5$, C-2'-H, C-6'-H), $7.11\left(1 \mathrm{H}, \mathrm{T}, \mathrm{J}=1.5\right.$, C-4'-H). ${ }^{13} \mathrm{C} \mathrm{NMR}\left(100.6 \mathrm{MHz}, \mathrm{CDCl}_{3}\right)$ : $20.6\left(\mathrm{CH}_{3}\right), 20.6\left(\mathrm{CH}_{3}\right), 20.7\left(\mathrm{CH}_{3}\right), 20.8$ $\left(\mathrm{CH}_{3}\right), 62.3$ (C-6), 68.8 (C-4), 71 (C-2), 72.5 (C-3), 72.7 (C-5), 83.6 (C-1), 115.9 (C-2', C-6'), 125.1 (C-4'), 123.2 (C-3', C-5'), $146.7\left(\mathrm{C}-1^{\prime}\right), 169.6(\mathrm{C}=\mathrm{O}), 169.9(\mathrm{C}=\mathrm{O}), 170.7(\mathrm{C}=\mathrm{O}), 171.3(\mathrm{C}=\mathrm{O})$. Calculated, \%: C 41.33; H 3.99; N 2.41. $\mathrm{C}_{20} \mathrm{H}_{23} \mathrm{Br}_{2} \mathrm{NO}_{9}$. Found, \%: C 41.40; H 4.01; N 2.39.

Mixture of $(2 R, 3 R, 4 R, 5 R, 6 R)-2$-(Acetoxymethyl)-6-(3,5-dibromophenylamino)tetrahydro-2H-pyran-3,4,5-triyl triacetate 14 and $(2 R, 3 R, 4 R, 5 R, 6 R)-2$-(Acetoxymethyl)-6-(3,5-dibromophenylamino)-5-hydroxytetrahydro- $2 \mathrm{H}$ pyran-3,4-diyl diacetate 15 in ratio 2:1. $[\alpha]_{\mathrm{D}}{ }^{16}-29.44$ ( c $0.119, \mathrm{CHCl}_{3}$ ). White solid. Yield $32 \%$.

Minor compound has been identified as 15. ${ }^{1} \mathrm{H}$ NMR (400 MHz, $\left.\mathrm{CDCl}_{3}, \delta, \mathrm{ppm}, \mathrm{J} / \mathrm{Hz}\right): 2.03$ (s, $\left.\mathrm{CH}_{3} \mathrm{CO}\right), 2.04$ (s, $\left.\underline{\mathrm{CH}}_{3} \mathrm{CO}\right), 2.05$ (s, $\left.\underline{\mathrm{CH}}_{3} \mathrm{CO}\right), 2.06$ (s, $\left.\underline{\mathrm{CH}}_{3} \mathrm{CO}\right), 2.07$ (s, $\underline{\mathrm{CH}}_{3} \mathrm{CO}$ ), 2.08 (d, $\left.\underline{\mathrm{CH}}_{3} \mathrm{CO}\right), 3.85-3.90$ (m), 4.04-4.10 (m), 4.11$4.1 \frac{13}{(d, ~ J=8), ~ 4.15-4.16 ~(t, ~ J=4), ~ 4.21-4.30 ~(m), ~ 5.01-5.02 ~(d, ~ J=4.5), ~ 5.03-5.04 ~(d, ~ J=4.7), ~ 5.16-5.20 ~(k v), ~ 5.30-5.32 ~(d, ~}$ $\mathrm{J}=5.2), 5.37$ (t, J=9.4), $6.74(2 \mathrm{H}, \mathrm{d}, \mathrm{J}=1.6) .6 .99(2 \mathrm{H}, \mathrm{d}, \mathrm{J}=1.6), 7.10(2 \mathrm{H}, \mathrm{d}, \mathrm{J}=1.6), 7.14(1 \mathrm{H}, \mathrm{d}, \mathrm{J}=1.6) .{ }^{13} \mathrm{C}$ NMR $(100.6$ $\left.\mathrm{MHz}, \mathrm{CDCl}_{3}\right): 20.6-20.8\left(\mathrm{CH}_{3}\right), 61.9,62.2,66.4,68.5,68.7,69.5,70.2,71.1,72.6,72.6,79.7,83.5,(\mathrm{C} 1-\mathrm{C} 6), 115.9$, 116.1 (C-2', C-6'), 123.4, 123.4 (C-4'), 125.1, 125.4 (C-3', C-5'), 146.7 147.2 (C-1'), 169.1, 169.5, 169.6, 169.9, 170.4, $170.7,171.3(\mathrm{C}=\mathrm{O})$. 


\section{2,6-Dibromo-4-nitroaniline 10}

To a heated solution (up to $\left.65^{\circ} \mathrm{C}\right)$ of 4-nitroaniline $9(11 \mathrm{~g}, 0.08 \mathrm{~mol})$ in $100 \mathrm{~mL}$ of glacial acetic acid under stirring is added drop wise a solution of bromine $(26 \mathrm{~g}, 0.16 \mathrm{~mol})$ in $60 \mathrm{~mL}$ of glacial acetic acid for 2 hours. After dropping of all bromine, the mixture was stirred for another 1.5 hours at the same temperature. The mixture was allowed to cool up to room temperature, next it was poured into a mixture, consisting of $500 \mathrm{~mL}$ of water and $250 \mathrm{~g}$ of ice and hold for 1.5 hours. The precipitate was filtered and washed 3 times with water to remove residual of acetic acid and dried at $100^{\circ} \mathrm{C}$, getting $22 \mathrm{~g}$ of product (melting at $199-200^{\circ} \mathrm{C}$ ). Yield $95 \%$. Further recrystallization from ethylene glycol monomethyl gives yellow-green crystals (prisms). Yellow-green prisms. M. p. 201-202 ${ }^{0}$ C. IR-spectra $\left(v / \mathrm{cm}^{-1}\right): 3417,1564\left(\mathrm{NH}_{2}\right)$, 1525, $1389\left(\mathrm{NO}_{2}\right), 1599$ (aromatics), 695 (C-Br). ${ }^{1} \mathrm{H}$ NMR (400 MHz, DMSO-d 6 , $\delta$, ppm, J/Hz): $6.69\left(2 \mathrm{H}, \mathrm{s}, \mathrm{NH}_{2}\right), 8.22$ (2H, s, C3-H and C5-H). ${ }^{13} \mathrm{C}$ NMR (100.6 MHz, CDCl $)$ ): 105.77 (C-Br), 128.3 (C-3 and C-5), 136.9 (C-4), 149.5 (C-1). Calculated, \%: C 24.35; $\mathrm{H} 1.36 ; \mathrm{N}$ 9.47. $\mathrm{C}_{6} \mathrm{H}_{4} \mathrm{Br}_{2} \mathrm{~N}_{2} \mathrm{O}_{2}$. Found, \%: C 24.42; H 1.34; $\mathrm{N} 9.51$.

\section{3,5-Dibromonitrobenzene 11}

To a heated up to $70^{\circ} \mathrm{C}$ solution of 2,6-dibromo-4-nitroaniline $10(20 \mathrm{~g}, 0.067 \mathrm{~mol})$ in $160 \mathrm{~mL}$ of ethanol, concentrated sulfuric acid $(11 \mathrm{~mL})$ is slowly added under stirring until the mixture become a homogeneous system. Next, sodium nitrite $(10 \mathrm{~g}, 0.14 \mathrm{~mol})$ is added in small portions, and the mixture is stirred at the same temperature about an hour, until precipitation. After that, the heating was stopped and the mixture was stirred before room temperature. Then $300 \mathrm{~mL}$ of water was added, the precipitate was filtered and washed 3 times with water to remove residual sodium nitrite. Further recrystallization from ethanol gives $14 \mathrm{~g}$ of product 11. The product is an orange solid. Yield $80 \%$. M. p. $110^{\circ} \mathrm{C}(\mathrm{EtOH})$. IR-spectra $\left(\mathrm{v} / \mathrm{cm}^{-1}\right): 1528,1336\left(\mathrm{NO}_{2}\right), 650(\mathrm{C}-\mathrm{Br}) .{ }^{1} \mathrm{H}$ NMR $\left(400 \mathrm{MHz}, \mathrm{CDCl}_{3}, \delta, \mathrm{ppm}, \mathrm{J} / \mathrm{Hz}\right): 7.98-7.99(1 \mathrm{H}, \mathrm{t}, \mathrm{J}=1.6)$, $8.31(2 \mathrm{H}, \mathrm{d}, \mathrm{J}=1.6) .{ }^{13} \mathrm{C}$ NMR (100.6 MHz, $\mathrm{CDCl}_{3}$ ): 123.47 (C-2 and C-6), 125.58 (C-Br), 140.05 (C-4), 149 (C-1). Calculated, \%: C 25.65; H 1.08; N 4.99. $\mathrm{C}_{6} \mathrm{H}_{3} \mathrm{Br}_{2} \mathrm{NO}_{2}$. Found, \%: C 25.72; H 1.06; N 5.02.

\section{3,5-Dibromoaniline 12}

To a solution of 3,5-dibromonitrobenzene $11(10 \mathrm{~g}, 0.035 \mathrm{~mol})$ in a 1:1 mixture of ethanol and THF (200 $\mathrm{mL})$ tin(II) chloride dihydrate $(40 \mathrm{~g}, 0.175 \mathrm{~mol})$ was added portionwise under stirring. The mixture was stirred at room temperature for 20 hours. After reaction solvents were removed in vacuo, $250 \mathrm{~mL}$ of water was added into remained orange liquid and dry alkali is added under stirring. Stirring was continued for 2 hours in strongly alkaline medium (pH 11-12). Next, the mixture was poured into separatory funnel, extra $150 \mathrm{~mL}$ of water was added. The reaction was extracted with diethyl ether $(4 \times 40 \mathrm{~mL})$, the combined organic phases were washed with water to remove residues of alkali, dried over anhydrous sodium sulfate and the solvent was removed. The resulting brown mass was purified by column chromatography on silica gel, using as eluent system petroleum ether-ethyl acetate (12:1). As a result, $7.5 \mathrm{~g}$ of product 12 have been obtained. Light brown solid. Yield $80 \%$. M. p. 55-56 ${ }^{\circ} \mathrm{C}$. IR-spectra $\left(\mathrm{v} / \mathrm{cm}^{-1}\right): 3417,1624\left(\mathrm{NH}_{2}\right), 1581$ (aromatics), $670(\mathrm{C}-\mathrm{Br}){ }^{~}{ }^{\mathrm{H}} \mathrm{NMR}\left(400 \mathrm{MHz}, \mathrm{CDCl}_{3}, \delta, \mathrm{ppm}, \mathrm{J} / \mathrm{Hz}\right): 3.78\left(2 \mathrm{H}, \mathrm{s}, \mathrm{NH}_{2}\right), 6.75(2 \mathrm{H}, \mathrm{d}, \mathrm{C} 2-\mathrm{H}, \mathrm{C} 6-\mathrm{H}, \mathrm{J}=1.5)$, $7.02(1 \mathrm{H}, \mathrm{t}, \mathrm{C} 4-\mathrm{H}, \mathrm{J}=1.5) .{ }^{13} \mathrm{C}$ NMR (100.6 MHz, $\left.\mathrm{CDCl}_{3}\right): 116.51$ (C-2 and C-6), 123.36 (C-Br), 123.70 (C-4), 148.64 (C-1). Calculated, \%: C 28.72; H 2.01; N 5.58. $\mathrm{C}_{6} \mathrm{H}_{5} \mathrm{Br}_{2} \mathrm{~N}$. Found, \%: C 28.77; H 2.00; N 5.60.

\section{Acknowledgments}

Author thanks Prof. Macaev F. and Dr. Barba A. for helpful discussions.

\section{References}

1. Kleeblatt, D.; Siyo, B.; Hein, M.; Iaroshenko, V.O.; Iqbal, J.; Villingera, A.; Langer, P. Synthesis of N,N'-diglycosylated isoindigos. Organic and Biomolecular Chemistry, 2013, 11, pp. 886-895.

2. Erben, F.; Kleeblatt, D.; Sonneck, M.; Hein, M.; Feist, H.; Fahrenwaldt, T.; Fischer, C.; Matin, A.; Iqbal, J.; Plötz, M.; Eberlee, J.; Langer, P. Synthesis and antiproliferative activity o selenoindirubins and selenoindirubin-N-glycosides. Organic and Biomolecular Chemistry, 2013, 11, pp. 3963-3978.

3. Kamano, Y.; Zhang, H.P.; Ichihara, Y.; Kizu, H.; Komiyama, K.; Pettit, G. R. Convolutamydine A, a novel bioactive hydroxyoxindole alkaloid from marine bryozoans Amathia convoluta. Tetrahedron Letters, 1995, 36, pp. 27832784.

4. Maskey, R.P.; Grün-Wollny, I.; Fiebig, H.H.; Laatsch, H. Akashins A, B, and C: Novel Chlorinated Indigoglycosides from Streptomyces sp. GW 48/1497. Angewandte Chemie International Edition, 2002, 41, pp. 597-599.

5. Maskey, R.P.; Grün-Wollny, I.; Laatsch, H. Isolation and structure elucidation of diazaquinomycin C from a terrestrial Streptomyces sp. and confirmation of the akashin structure. Natural Product Research, 2005, 19, pp. 137-142.

6. Zhang, H.P.; Kamano, Y.; Ichihara, Y.; Kizu, H.; Komiyama, K.; Itokawa, H.; Pettit, G.R. Isolation and structure of convolutamydines B -D from marine bryozoans Amathia convoluta. Tetrahedron, 1995, 51, pp. 5523-5528. 